\title{
Occupational stress of nurses from the Mobile Emergency Care Service
}

\author{
Estresse ocupacional de enfermeiros do Serviço de Atendimento Móvel de Urgência \\ Estrés laboral de enfermeros en la Atención Móvil de Urgencia
}

\author{
Alessandra Ferreira Araújo' \\ ORCID: 0000-0003-1490-0758 \\ Luciana Neves da Silva Bampi \\ ORCID: 0000-0003-0792-759X \\ Caio Cesar de Olivera Cabral \\ ORCID: 0000-0002-2566-0414 \\ Rayanne Silva Queiroz \\ ORCID: 0000-0002-5191-3534 \\ Luiza Helena Brito Calasans \\ ORCID: 0000-0002-3738-8171 \\ Tiago Silva Vaz" \\ ORCID: 0000-0002-7553-9866
}

'Universidade de Brasília. Brasília, Distrito Federal, Brazil. "Secretaria de Estado de Saúde do Distrito Federal, Serviço de Atendimento Móvel de Urgência. Brasília, Distrito Federal, Brazil.

How to cite this article: Araujo AF, Bampi LNS, Cabral CCO, Calasans LHB, Queiroz RS, Vaz TS. Occupational stress of nurses from the Mobile Emergency Care Service.

Rev Bras Enferm. 2020;73(Suppl 1):e20180898. doi: http://dx.doi.org/10.1590/0034-7167-2018-0898

Corresponding author:

Alessandra Ferreira Araújo

E-mail: ale.focuda@gmail.com

EDITOR IN CHIEF: Antonio José de Almeida Filho ASSOCIATE EDITOR: Rafael Silva

Submission: 02-19-2019

Approval: 08-17-2019

\section{ABSTRACT}

Objective: To evaluate stress, and to associate it with sociodemographic and clinical aspects of nurses from the Mobile Emergency Care Service. Method: This is an observational, crosssectional and quantitative study conducted with 123 nurses, who answered a questionnaire to assess sociodemographic and clinical variables, and the Job Stress Scale, which evaluates stress in the workplace. Results: The results indicated that most of them were women, 20 to 40 years old, married, without another employment bond and with specialization course. They had low control and low demand at work and performed a passive work. Women reported passive work and high stress levels, while men were equally divided in active and passive work with low stress levels. Conclusion: Passive work is harmful to health and it is related to lack of autonomy, decision-making, and social support. It may lead to reduced ability to solve problems faced in daily work routine.

Descriptors: Nurses; Emergency Nursing; Emergency Medical Services; Occupational Stress; Occupational Health.

\section{RESUMO}

Objetivo: Avaliar o estresse, associando-o aos aspectos sociodemográficos e clínicos de enfermeiros do Serviço de Atendimento Móvel de Urgências. Método: Trata-se de estudo observacional, transversal e quantitativo, realizado com 123 enfermeiros, que responderam a um questionário, para conhecer variáveis sociodemográficas e clínicas. Foi utilizada a Job Stress Scale, que avalia o estresse no trabalho. Resultados: Os resultados indicaram que a maioria eram mulheres, de 20 a 40 anos, casadas, sem outro vínculo empregatício e com especialização. Possuíam baixo controle, baixa demanda no trabalho e executavam trabalho considerado passivo. As mulheres referiram trabalho passivo e alto desgaste, enquanto os homens dividiram-se igualmente entre o perfil ativo e passivo com baixo desgaste. Conclusão: $\mathrm{O}$ trabalho passivo é nocivo à saúde e está relacionado à falta de autonomia, de poder de decisão e de suporte social. Pode conduzir à redução da capacidade de produzir soluções para os problemas enfrentados no cotidiano laboral. Descritores: Enfermeiros; Enfermagem em Emergência; SAMU; Estresse Ocupacional; Saúde do Trabalhador.

\section{RESUMEN}

Objetivo: evaluar el estrés y asociar los aspectos sociodemográficos y clínicos de los enfermeros que trabajan en el Atendimiento Móvil de Emergencias. Método: Este fue un estudio observacional, transversal y cuantitativo realizado con 123 enfermeros, que respondieron un cuestionario para conocer las variables sociodemográficas y clínicas, y la Job Stress Scale. Resultados: Los resultados indicaron que la mayoría eran mujeres, de 20 a 40 años, sin ninguna otra relación laboral ni especialización. Tenían bajo control y baja demanda en el trabajo y realizaron un trabajo considerado pasivo. Las mujeres reportaron trabajo pasivo y desgaste elevado, mientras que los hombres se dividieron entre trabajo activo y pasivo con desgaste bajo. Conclusión: el trabajo pasivo es perjudicial para la salud y está relacionado con la falta de autonomía y el poder de decisión. Puede llevar a una capacidad reducida para producir soluciones a los problemas que se enfrentan en el trabajo diario. Descriptores: Enfermeros; Enfermería de Urgencia; Servicios Médicos de Urgencia; Estrés Laboral, Salud Laboral. 


\section{INTRODUCTION}

Stress exerts a direct influence on personal and professional life of all individuals, and it may cause disruption in internal balance of the organism ${ }^{(1)}$. It may have an external origin, related to the profession, disagreements, losses, or an internal origin regarding the individual's way of being, beliefs, morals and way of acting. Workplace is the external factor that most relate to development of stress ${ }^{(2)}$.

A new perspective of studies on worker's health has highlighted absence of neutral relations between work and health/ disease process, reinforcing the conception that every productive activity has a potential to promote health or to produce disease, depending on how elements of organization and work process are configured and how they articulate with the subjective characteristics of the worker ${ }^{(3)}$.

Occupational stress has become one of the main causes of illness. It is an important risk factor for the individual's psychosocial well-being, directly affecting health and quality of life, resulting in poor performance, high turnover, absenteeism and violence in workplace ${ }^{(4)}$. Thus, several theoretical and methodological proposals have been elaborated in order to present models to study this factor. Among the proposals, the Job Strain Model, developed by Karasek ${ }^{(5)}$, has become a reference model.

Robert Karasek was one of the first researchers looking for sources of stress and their health repercussions in social relations of workplace ${ }^{(6)}$. In the 1970s, he proposed a two-dimensional theoretical model that related two aspects - demands and control at work - to the risk of illness. Demands are psychological pressures, whether quantitative, such as time and speed in performing tasks, or qualitative, such as conflicts with contradictory situations ${ }^{(6)}$. Control is the ability of the worker to use his intellectual skills to perform activities, as well as having sufficient authority to make decisions on how to perform them ${ }^{(7-8)}$. From the combination of these two dimensions, the model distinguishes situations of specific work that structure different health risks ${ }^{(9)}$.

There are a lot of diverse unhealthy aspects in work environment, they interact with each other and affect the psychosocial environment of the institution ${ }^{(10)}$. Pre-hospital care (PHC) is defined as any care provided outside the hospital environment and health networks, where the event occurred, for people at risk $^{(11)}$. In pre-hospital care (PHC), the process and organization of nursing work are marked by relationships with potential for harm to workers' health ${ }^{(12)}$. This type of work has as its object the care of severely ill people who need immediate attention and who are at life risk ${ }^{(13)}$. Pain, suffering, helplessness, anguish, fear, hopelessness, feelings of abandonment and loss permeate emergencies and constitute psychological demands with possible unhealthy effect on workers' health and quality of life ${ }^{(10,12)}$.

Studies have highlighted and discussed stress in professionals who work in hospital emergency services, however, the levels of stress in PHC are not properly clarified ${ }^{(13)}$. Nurses who work in PHC attend their patients in public or home spaces. These professionals require preparation and speed to deal with adverse external conditions, such as exposure to infections, contaminated biological material, chemicals, stress, inadequate lighting, hard to reach places, violence, among others ${ }^{(14)}$. These work characteristics make the work done in PHC units unhealthier ${ }^{(15)}$.
Pre-hospital care was established in Brazil through Ordinance $n^{\circ} 1864 / 2003$, which implements the Mobile Emergency Care Service (SAMU) in Brazil(15). The Nurse, along with the care staff, assumes responsibility for the care provided to the victim through the prediction of needs, priorities setting and initiating necessary interventions in order to stabilize the patient during transport for definitive treatment ${ }^{(16)}$. Among them, incorporation of increasingly technical and specialized activities, strong pressure decision-making and problems solving stand out ${ }^{(17)}$.

\section{OBJECTIVE}

To evaluate work stress, and to associate it with sociodemographic and clinical aspects of the Mobile Emergency Care Service nurses from the Federal District (SAMU FD).

\section{METHODS}

\section{Ethical Aspects}

The protocol of this study was approved by the Research Ethics Committees of the Health Sciences course in the University of Brasilia and the Health Sciences Teaching and Research Foundation of the State Department of Health from the Federal District. According to the guidelines provided for Resolution $\mathrm{n}$. 466 of 2012 of the National Health Council of the Ministry of Health, the ethical aspects were fully guaranteed. The Informed Consent Form (ICF) was applied in two copies, one of which was provided to the participant.

\section{Design, setting and period of study}

This is an observational, cross-sectional and quantitative study. Data collection occurred at SAMU FD units, by the researcher in a reserved place. Nurses previously scheduled the meeting, according to the service timetable and availability to participate, not interfering with the work process. Data collection occurred in 2016.

\section{Population, inclusion and exclusion criteria}

Nurses from SAMU FD were included in the study, enrolled at the Federal District State Department of Health (SDHFD) and registered at the Federal District Regional Nursing Council, as a higher level nursing professional. Nurses who did not meet the inclusion requirements were excluded. Thus, the population invited to participate in the study had 160 professionals, which 9 were on maternity or health leave, 2 no longer worked in the institution, 5 refused to participate and 16 were not found, totaling 128 participants. Due to irregularities in filling (missing values), 5 questionnaires were invalidated, thus, 123 nurses formed the studied sample.

\section{Study Protocol}

In order to know the sociodemographic and clinical aspects, a specific instrument was created with data regarding gender, age, nationality, origin, marital status, number of children, working time at SAMU FD, PHC Nucleus in which the participant worked, another employment relationship (or two enrollments at SDH 
FD), time to conclude the graduation, postgraduate conclusion, presence of chronic disease and continuous medications intake.

To evaluate work stress, we used the short version of the Job Stress Scale (JSS) adapted and validated to Brazilian Portuguese ${ }^{(6)}$, which has been used in other studies with nurses ${ }^{(18-21)}$.

The scale, developed by Karasek, defines 4 categories: high requirement (high wear), active work, low requirement (low wear) and passive work ${ }^{(9)}$. High requirement work (high demand and low worker control over work) is considered the most demanding ${ }^{(18)}$. Workers continuously exposed to this type of work may have fatigue, anxiety, depression and physical illness ${ }^{(9)}$. Active work (high demand and high worker control) presents an intermediate risk for stress, because although there are high demands, there is positive learning and use of the individual's intellectual skills, which develops motivation ${ }^{(6)}$. Low wear (low demand and high control) is the least harmful to the worker, it is considered ideal because it allows the professional to control tasks and to use skills ${ }^{(6)}$. Passive work (low demand and low control) may lead to a decline in the individual's global activity and the reduction in the ability to produce solutions to the activities and problems faced, since workplace is considered as poorly motivated ${ }^{(5,7)}$.

A third dimension, social support in workplace, was added to the model by Johnson, in 1988. It refers to the level of social interaction with bosses and colleagues. The scarcity of a support network in this context can also have negative health consequences ${ }^{(6)}$.

JSS has 17 questions, organized in 3 dimensions: Psychological demands of work (questions 1 to 5); Control over work (questions 6 to 11 ) and Social support (questions 12 to 17$)^{(6)}$. The score of each dimension is obtained by adding the points attributed to each questions ${ }^{(6)}$.

\section{Result analysis and Statistics}

Data were collected by a previously trained team. A database was organized in Microsoft Excel and analyzed using the Statistical Package for Social Sciences (SPSS) program, version 24.0. Statistical analyzes performed descriptive analyzes of frequency, central tendency and dispersion and inferential analyzes.

To calculate JSS scores, each dimension was dichotomized into low and high. For this dichotomization, a normality analysis was conducted. Due to the non-normal distribution of data, we used the median value to define the categories of each dimension. The median is the action of central tendency indicated when the data found do not present a normal distribution. Psychological demands of work were defined as: low demand $(\leq 8)$, high demand $(\geq 9)$. Control over work: Low control $(\leq 10)$ and high control $(\geq 11)$. From the demand (high and low) and control (high and low) dimensions, we defined the quadrants of demand-control model in high work stress (high psychological demand and low control), active work (high psychological demand and high control), passive work (low psychological demand and low control) and low wear (low psychological demand and high control) ${ }^{(5-6)}$. Social support dimension scores were defined by the median and dichotomized into low support $(M \leq 12)$ or high support $(M \geq 13)$.

To compare proportions among categories of the same variable, we used the Chi-square test. A probability of type I (a) error of 0.05 was considered for all inferential analyzes.

\section{RESULTS}

The characterization of the studied sample showed that the SAMU FD nurse team consisted of 91 (74\%) women and 32 (26\%) men, with 80 nurses $(65.2 \%)$ aged between 20 and 40 years old, 78 nurses (63.4\%) were married (63.4\%), 104 (84.6\%) with more than 4 years of work experience in the service, 81 (65.9\%) without any other employment bond, 54 (43.9\%) worked in the mobile service, 47 (38.2\%) in fixed emergencies, such as Trauma and Neurocardiovascular Center, located at the Base Hospital from the Federal District, and Guara Emergency Center, at Guara Regional Hospital, and 22 (17.9) in regulation, management or teaching.

Regarding academic background, 109 (88.6\%) graduated more than 5 years ago, 86 (70\%) had a specialization course, 7 (5.7\%) did a medical residency, 7 (5.7\%) had a master's degree and only $1(0.8 \%)$ had PhD. Regarding health, we observed that 19 (15.4\%) nurses had some chronic disease and 37 (30.1\%) use some type of continuous medicine.

Table 1 - Job Stress Scale dimensions of SAMU FD nurses, Brasilia, Federal District, Brazil, $2017(\mathrm{~N}=123)$

\begin{tabular}{ll}
\hline Variables & n (\%) \\
\hline $\begin{array}{l}\text { Psychological demand } \\
\text { Low demand }(\downarrow D)\end{array}$ & $73(59.3)$ \\
High demand $(\uparrow \mathrm{D})$ & $50(40.7)$ \\
Control over work & \\
Low control $(\downarrow C)$ & $72(58.5)$ \\
High controle $(\uparrow C)$ & $51(41.5)$ \\
Demand-control quadrants & \\
Low wear $(\downarrow D \uparrow C)$ & $27(22.0)$ \\
Active ( $\uparrow \uparrow C)$ & $25(20.3)$ \\
Passive $(\downarrow D \downarrow C)$ & $46(37.4)$ \\
High wear $(\uparrow D \downarrow C)$ & $25(20.3)$ \\
Social support & \\
Low support $(\downarrow A)$ & $78(63.4)$ \\
High support $(\uparrow A)$ & $45(36.6)$ \\
\hline
\end{tabular}

Table 2 - Distribution of demographic variables according to demandcontrol quadrants of the Job Stress Scale, Brasilia, Federal District, Brazil, 2017

\begin{tabular}{|c|c|c|c|c|c|c|}
\hline \multirow[b]{2}{*}{$\begin{array}{l}\text { Demographics } \\
\text { Variables }\end{array}$} & \multicolumn{6}{|c|}{ Demands-control quadrants n (\%) } \\
\hline & $\mathbf{n}$ & $\begin{array}{c}\text { Low } \\
\text { Wear } \\
\mathbf{n}=\mathbf{2 7}\end{array}$ & $\begin{array}{c}\begin{array}{c}\text { Passive } \\
\text { Work }\end{array} \\
\text { n }=46\end{array}$ & $\begin{array}{l}\begin{array}{c}\text { Active } \\
\text { Work }\end{array} \\
\mathbf{n}=\mathbf{2 5}\end{array}$ & $\begin{array}{l}\text { High } \\
\text { Wear } \\
n=25\end{array}$ & $p$ \\
\hline Gender & & & & & & $0.013^{*}$ \\
\hline Male & 32 & $6(18.8)$ & $12(37.5)$ & $12(37.5)$ & $2(6.2)$ & \\
\hline Female & 91 & $21(23.1)$ & $34(37.4)$ & $13(14.3)$ & $23(25.2)$ & \\
\hline Age & & & & & & $0.942^{*}$ \\
\hline 20 to 40 years old & 80 & $18(22.5)$ & $31(38.8)$ & $16(20.0)$ & 15 (18.7) & \\
\hline Over 41 years old & 43 & $9(20.9)$ & $15(34.9)$ & $9(20.9)$ & $10(23.3)$ & \\
\hline Marital Status & & & & & & $0.624^{*}$ \\
\hline Single & 26 & $4(15.4)$ & $9(34.6)$ & $6(23.1)$ & $7(26.9)$ & \\
\hline Married & 78 & $20(25.6)$ & $31(39.8)$ & $15(19.2)$ & $12(15.4)$ & \\
\hline Separated & 4 & $1(25.0)$ & $1(25.0)$ & $0(0.0)$ & $2(50.0)$ & \\
\hline Divorced & 14 & $2(14.3)$ & $5(35.7)$ & $3(21.4)$ & $4(28.6)$ & \\
\hline Widow/Widower & 1 & $0(0.0)$ & $0(0.0)$ & $1(100.0)$ & $0(0.0)$ & \\
\hline Children & & & & & & $0.850^{*}$ \\
\hline Childless & 35 & $9(25.7)$ & $12(34.3)$ & $8(22.9)$ & $6(17.1)$ & \\
\hline 1 child & 44 & $10(22.7)$ & $17(38.7)$ & $10(22.7)$ & $7(15.9)$ & \\
\hline 2 children & 33 & $6(18.2)$ & $13(39.4)$ & $5(15.2)$ & $9(27.2)$ & \\
\hline 3 children & 6 & 1 (16.7) & $3(50.0)$ & $2(33.3)$ & $0(0.0)$ & \\
\hline 4 or more children & 4 & $1(25.0)$ & $1(25.0)$ & $0(0.0)$ & $2(50.0)$ & \\
\hline
\end{tabular}


Regarding the dimensions evaluated by JSS, 73 (59.3\%) nurses reported having low Psychological demand at work and 72 (58.5\%) reported low Control over work. Regarding the Demand-control quadrants, we observed that $46(37.4 \%)$ professionals had passive profile (passive work) and 78 (63.4\%) described low perception of Social support (Table 1).

In the associations of sociodemographic and clinical data with dimensions of JSS, we observed a higher number of passive work (Table 2). The inferential analysis allowed us to state that among the demographic variables, only gender is related to the distribution of Demand-control quadrants $\left(X^{2}(3)=10.695 ; p \leq 0.01 ; N=123\right)$.

\section{DISCUSSION}

The sociodemographic and clinical profile of SAMU FD nurses showed that most of the participants were women under the age of 40 years old with an expert course degree. Another study also found this profile for the nursing staff in Brazil(22). A study conducted by UDESC found the predominant age range among professionals: 31 and 40 years old and marital status: married, the time worked in the urgency and emergency sectors was from 1 to 10 years $^{(23)}$.

In JSS evaluation, regarding control, 72 (58.5\%) nurses reported low Control over work. It is worrying because it characterizes repetitive work process, with low autonomy and few opportunities for new learning ${ }^{(10)}$. This aspect can cause demotivation and low self-esteem of the worker, which is harmful to the professional's health ${ }^{(10)}$. Control over how to do their job is a challenge and it encourages the worker in work activities ${ }^{(24)}$.

We identified low Psychological demand in SAMU FD nurses, $73(59.3 \%)$ professionals. A study conducted with the nursing staff of a state public first-aid in Rondonia showed that most workers had low psychological demand $(66.1 \%)^{(25)}$.

In demand-control quadrants evaluation, the studied group had higher frequency of passive work, 46 (37.4\%) nurses. Another study also pointed more frequently to passive work among nurses $(38.10 \%)^{(25)}$. This type of work was also the most frequent in a study conducted with 388 nursing professionals in a first-aid in Southern Brazil (35.6\%) ${ }^{(9)}$. A study conducted with 491 nurses in a hospital-school in Rio Grande do Sul ${ }^{(10)}$, showed that $30 \%$ of the professionals were classified in passive work group.

Passive work (low demand and low control) leads to a gradual reduction in the ability to solve general problems in workplace ${ }^{(25)}$. Professionals experience boredom and dissatisfaction related to repetition of tasks and decreased ability to face intellectual challenges ${ }^{(26)}$. Observation and follow-up are required, because passive work can cause loss of skills and interest at work ${ }^{(6)}$.

According to Karesk, related studies suggest that employees with low decision-making power and low psychological demands face different problems related to passivity and apathy. Passive jobs with low demands as well as low decision-making skills, are unsatisfactory $^{(5)}$. The passive profile is not an ideal situation, since the work environment is considered as little motivating, leading to a negative learning ${ }^{(27)}$. The studied model predicts that passive work can lead to a decline in individual's global activity and to a reduction in the ability to produce solutions to the activities and problems faced ${ }^{(9)}$.
Lack of autonomy, decision-making power, innovation and intellectual development harm health and hinder the development of creative and resolute work ability. Autonomy, power to decide and creative and resolute work ability are important tools to combat stress. Thus, SAMU FD should adopt a management model that encourages the participation of professionals in the processes, spaces for shared deliberation, as well as making possible the creation and development of new tools and interventions for health care. These actions would help in combating work stress in the institution.

The evaluation of social support showed that most SAMU FD nurses, 78 (63.4\%), consider it a low dimension, that is, do not receive support from bosses and colleagues. Another study showed that low social support was perceived by $51.9 \%$ of workers ${ }^{(21)}$. A study conducted with nursing professionals of a hospital in Jequie indicated that $47.2 \%$ of nurses consider that the social support received is low ${ }^{(21)}$.

A study conducted with 185 nursing professionals from Parana Public Hospitals showed that lower perceptions of social support received from bosses and colleagues at work were associated with stressful work ${ }^{(28)}$.

Some studies have shown that lack of supportive work makes workers more likely to cardiovascular diseases, stress, physical and emotional exhaustion ${ }^{(25)}$. The mechanisms by which social support in workplace affects health, well-being and quality of life are diverse. It can act as an attenuating mechanism for unhealthy effects of psychosocial work stressors, enhancing the development of new skills or behaviors, as well as stimulating the acquisition/improvement of coping strategies ${ }^{(25)}$. The service should work to improve interaction among professional staff members, in order to involve professionals in the work performed and promote coping with stress.

When sociodemographic and clinical data were related to the dimensions of JSS, it indicated that only gender determined distribution of quadrants. The other sociodemographic and clinical data did not obtain statistically significant association. More women had passive work and high wear, while the number of men who showed active work was equal to passive work and there were more men with low wear. This could be related to the double workday, which involves women. In addition to the activities performed at SAMU FD, they take care of family, children, and domestic activities. According to Karesk, the relationship between work and mental state for women is often complicated by the additional demand for household chores $^{(29)}$.

\section{Limitations of the study}

The observational and cross-sectional study design did not allow monitoring the temporal evolution of occupational stress from SAMU nurses. As well as made it impossible to know its relationship with sociodemographic and clinical aspects over time. However, the proposed design allowed us to know the main causes related to this serious problem to the worker's health.

\section{Contributions to the area}

The research addresses a relevant topic for nurses, especially workers of emergency medical services. The article deals with stress at work, a topic little explored in the area. It reveals that the professional profile is mostly passive and that there is low social 
support for the execution of activities, which implies intense stress for the professional. The results of the research may support the elaboration of policies and strategies to deal with this problem that interferes with workers' health and causes illness with consequent low productivity, absenteeism, sick leave and even early retirement.

\section{CONCLUSION}

This study demonstrated the factors that cause stress at work and their importance for SAMU FD nurses. Low psychological demand and low control over work in the service, in nurses opinion, can be harmful to health and also cause stress. In addition, passive work discourages the professional, causing loss of skills, dissatisfaction and lack of work interest. We also found low social support and low levels of social interaction with bosses and colleagues at work can cause negative health consequences.

Despite the limitations imposed by the observational and cross-sectional study design, the results were consistent with the literature, revealing the importance of working conditions on nurses' health.

\section{REFERÊNCIAS}

1. Lipp MEN. O Stress está dentro de você. Organização 2a ed. São Paulo: Contexto; 2000. p. 12

2. Rodrigues CCFM, Santos VEP. The body speaks: physical and psychological aspects of stress in nursing professionals. Rev Pesqui: Cuid Fundam. 2016;8(1):3587-96. doi: 10.9789/2175-5361.rpcfo.v8.2849

3. Dejours C. Psicodinâmica do Trabalho: contribuições da escola Dejouriana à análise da relação prazer, sofrimento e trabalho. São Paulo: Atlas; 2010. p 145.

4. Petarli GB, Zandonade E, Salaroli LB, Bissoli NS. Estresse ocupacional e fatores associados em trabalhadores bancários, Vitória - ES, Brasil. Ciênc Saúde Coletiva [Internet]. 2015 [cited 2016 Nov 15];20(12):3925-34. Available from: http://www.scielo.br/pdf/csc/v20n12/1413-8123csc-20-12-3925.pdf

5. Karasek RA. Job demands, job decision latitude, and mental strain: implications for job redesign. Adm Sci Q. 1979;24:285-308

6. Alves MGM, Chor D, Faerstein E, Lopes CS, Werneck GL. Versão resumida da "job stress scale": adaptação para o português. Rev Saúde Pública [Internet]. 2004 [cited 2017 Apr 4];38(2):164-71: Available from: http://www.scielo.br/pdf/rsp/v38n2/19774.pdf

7. Theorell T. The demand-control-support model for studying health in relation to the work environment: an interactive model. In: Orth-Gómer K, Schneiderman N, editors. Behavioral medicine approaches to cardiovascular disease. Mahwah, NJ: Lawrence Erlbaum Associates; 1996. p. 69-85.

8. Theorell T, Karasek RA. Current issues relating to psychosocial job strain and cardiovascular diseasse research. J Occup Health Psychol [Internet]. 1996[cited 2017 Apr 4];1:9-26. Available from: https://www.ncbi.nlm.nih.gov/pubmed/9547038

9. Araújo TMD, Graça CC, Araújo E. Estresse ocupacional e saúde: contribuições do Modelo Demanda-Controle. Ciênc Saúde Coletiva [Internet]. 2003 [cited 2017 Apr 4];8(4):991-1003. Available from: http://www.scielo.br/pdf/csc/v8n4/a21v8n4.pdf

10. Urbaneto JS, Silva PC, Hoffmeister E, Negri BS, Costa BEP, Figueiredo CEP. Workplace stress in nursing workers from an emergency hospital: Job Stress Scale analysis. Rev Latino-Am Enfermagem. [Internet]. 2011 [cited 2017 Apr 4];19(5):1122-31. Available from: http://www.scielo. br/pdf/rlae/v19n5/pt_09.pdf

11. Sé ACS, Silva, Figueiredo NMA. Ambientes do cuidar e a Síndrome de Burnout: um estudo com enfermeiros do pré-hospitalar. Rev Baiana Enferm [Internet]. 2017 [cited 2019 Apr 2];31(3). Available from: https://portalseer.ufba.br/index.php/enfermagem/article/view/17931

12. Dal Pai D, Lautert L. Work under urgency and emergency and its relation with the health of nursing professionals. Rev Latino-Am Enfermagem [Internet]. 2008 [cited 2017 Apr 4];16(3):439-44. Available from: http://www.scielo.br/pdf/rlae/v16n3/pt_17.pdf

13. França SPS, De Martino MMF, Aniceto EVS, Silva LL. Preditores da Síndrome de Burnout em enfermeiros de serviços de urgência pré-hospitalar. Acta Paul Enferm [Internet]. 2012 [cited 2017 Apr 4];25(1):68-73. Available from: http://www.scielo.br/pdf/ape/v25n1/v25n1a12.pdf

14. Silva AM, Guimarães LAM. Stress and Quality of Life in Nurses. Paidéia 2016; 26(63): 63-70. doi: 10.5205/1981-8963-v12i12a236158p3378-3385-2018

15. Tavares TY, Santana JCB, Eloy MD, Oliveira RD, Paula RF. O cotidiano dos enfermeiros que atuam no serviço de atendimento móvel de urgência. Rev Enferm Centro O Min [Internet]. 2017 [cited 2018 Jul 4];7(0). Available from: http://www.seer.ufsj.edu.br/index.php/recom/ article/view/1466

16. Antonio MCR, Candi MCFS, Contrera L, Duarte SJH, Furegato ARF, Pontes ERJC. Alterações de saúde e sintomas sugestivos de depressão entre trabalhadores da enfermagem do serviço de atendimento móvel de urgência. Enferm Foco [Internet]. 2014 [cited 2018 Jul 4];5(1/2):47. Available from: http://revista.cofen.gov.br/index.php/enfermagem/article/view/595

17. Adriano MSPF, Almeida MR, Ramalho PPL, Costa IP, Nascimento ARS, Moraes JCO. Estresse Ocupacional em Profissionais da Saúde quem atuam no Serviço de Atendimento móvel de Urgência de Cajazeiras - PB. Rev Bras Ciênc Saúde [Internet].2016 [cited 2019 Apr 4];21(1):2934. Available from: http://www.periodicos.ufpb.br/index.php/rbcs/article/view/16924

18. Ribeiro RP, Marziale MHP, Martins JT, Galdino MJQ, Ribeiro PHV. Estresse ocupacional entre trabalhadores de saúde de um hospital universitário. Rev Gaúcha Enferm [Internet]. 2018 [cited 2019 Apr 4];39:e65127. Available from: http://www.scielo.br/pdf/rgenf/v39/ en_1983-1447-rgenf-39-e65127.pdf 
19. Petersen R de S, Marziale MHP. Análise da capacidade no trabalho e estresse entre profissionais de enfermagem com distúrbios osteomusculares. Rev Gaúcha Enferm. 2018;38(3):e67184. doi: 10.1590/1983-1447.2017.03.67184

20. Teixeira CAB, Gherardi-Donato ECS, Pereira SS, Cardoso L, Reisdorfer E. Estresse Ocupacional e estratégias de enfrentamento entre os profissionais de enfermagem em ambiente hospitalar. Enferm Glob. 2016;15(44):288-98. doi: 10.5327/Z1679443520180279

21. Azevedo BDS, Nery AA, Cardoso JP. Estresse Ocupacional e insatisfação com a qualidade de vida no trabalho da enfermagem. Texto Contexto Enferm. 2017;26(1):e3940015. doi: 10.1590/0104-07072017003940015

22. Machado MH, Aguiar Filho W, Lacerda WF, Oliveira E, Lemos W, Wermelinger M, et al. Características Gerais da Enfermagem: O Perfil sociodemográfico. Rev Latino-Am Enfermagem [Internet]. 2016 [cited 2016 Feb 20]. Available from: http://www.cofen.gov.br/ perfilenfermagem

23. Kolhs M, Olschowsky A, Barreta NL, Schimerfening J, Vargas RP, Busnello GF. A enfermagem na urgência e emergência: entre o prazer e o sofrimento. Rev Pesqui: Cuid Fundam [Internet]. 2017 [cited 2017 Sep 14];9(2):422-31. Available from: http://www.seer.unirio.br/index.php/ cuidadofundamental/article/view/5427

24. Costa MFAA, Ferreira MC. Sources and Reactions to Stress in Brazilian Lawyers. Paidéia. 2014;24(57):49-56. doi: $10.1590 / 1982-43272457201407$

25. Kogien M, Cedaro JJ. Public emergency department: the psychosocial impact on the physical domain of quality of life of nursing professionals. Rev Latino-Am Enfermagem [Internet]. 20142017 [cited 2017 Sep 14];22(1):51-8. Available from: http://www.scielo.br/pdf/ rlae/v22n1/pt_0104-1169-rlae-22-01-00051.pdf

26. Araújo TM, Aquino E, Menezes G, Santos CO, Aguiar L. Aspectos psicossociais do trabalho e distúrbios psíquicos entre trabalhadores de enfermagem. Rev Saúde Pública [Internet]. 2017 [cited 2017 Sep 14];37(4):424-33. Available from: http://www.scielo.br/pdf/csc/v8n4/ a21v8n4.pdf

27. Karasek R, Brisson C, Kawakami N, Houtman I, Bongers P, Amick B. The Job Content Questionnaire (JCQ): an instrument for internationally comparative assessments of psychosocial job characteristics. J Occup Health Psychol 1998;3(4):322-355.

28. Scholze AR, Martins JT, Robazzi MLCC, Haddad MCFL, Galdino MJQ, Ribeiro RP. Estresse ocupacional e fatores associados entre enfermeiros de hospitais públicos. Cogitare Enfermagem [Internet]. 2017 [cited 2017 Apr 4];22(3). Available from: https://revistas.ufpr.br/cogitare/article/ view/50238

29. Karasek, Robert A. The Impact of the Work Environment on Life Outside the Job [Thesis]. Massachusetts Institute of Technology. Institute for Social Research, Stockholm University. 1976. 